\title{
THE EFFECT OF RAIN ON $\beta$-GLUCAN CONTENT IN BARLEY GRAINS
}

\author{
by \\ STEN AASTRUP \\ Department of Biotechnology, Carlsberg Research Laboratory, \\ Gamle Carlsberg Vej 10, DK-2500 Copenhagen Valby \\ and \\ Institute of Genetics, University of Copenhagen, \\ Øster Farimagsgade 2A, DK-1353 Copenhagen K
}

Keywords: Viscosity, $\beta$-glucan, acid extract, barley, rain effect, high lysine

The effect of rain on the viscosity of an acid flour extract and on the acid-soluble, acid-insoluble and total $\beta$ glucan contents of barley flour has been investigated. Four commercial varieties and two high lysine genotypes were studied. In the commercial varieties rain induces a decrease in the viscosity of the acid flour extract which is paralleled by decreases in soluble and total $\beta$-glucan contents. Furthermore, it is concluded that the rain did not alter the structural nature of the acid-soluble $\beta$-glucans. The genotype having the lys-3a allele is characterized by such a low extract viscosity and $\beta$-glucan content that the rain had no effect on these parameters. The rain had a very unexpected effect on the genotype having the lys allele, namely, a marked decrease in extract viscosity that was not accompanied by a decrease in $\beta$-glucan contents. Similar analyses on pure endosperm demonstrated that the rain effect is not a result of an altered 1000-grain weight. In addition, the extract viscosity and the soluble $\beta$ glucan content were found to decrease from yellow to full ripeness.

\section{INTRODUCTION}

The cell walls of barley endosperm comprise $75 \%$ mixed-linked $\beta$-glucans ${ }^{\prime}$ (7). Consequently they play an important structural role. Half of these $\beta$-glucans, however, can be removed by water without destroying the cell wall structure

1 Polymers of $\beta$-D-glycopyranose ( 16 ) in 1,3 and 1,4 linkages (4) which in the present communication are referred to as $\beta$-glucans.
(8). Both genotype (1) and environmental conditions (17) have been shown to influence the highly variable amount of $\beta$-glucans. Such findings have led to the suggestions that the $\beta$ glucans of the endosperm cell walls, in addition to their structural function, may serve as reserve material and/or may take part in osmoregulation because of their hygroscopic nature. The latter characteristic has been observed several times (FulCher, pers. comm.). As a first step in 
demonstrating such functions for the $\beta$-glucans, it is necessary to determine exactly which environmental parameters alter the amount of $\beta$ glucan. These parameters can be studied individually in a phytotron.

It is a general observation that a wet harvest results in barley grains whose flour is characterized by a low extract viscosity and $\beta$-glucan content, while a dry harvest yields grains whose flour has a high extract viscosity and $\beta$-glucan content. Therefore, possible relationships between barley extract viscosities and $\beta$-glucan contents have often been discussed (see 1). Such a correlation has now in fact been demonstrated (1). In addition a ripening effect has been shown by GoHL (10), who found that the viscosity of barley extracts was highest in grains harvested at yellow ripeness. Therefore, the effect of rain on extract viscosity and $\beta$-glucan contents of grains harvested at different stages of ripeness was investigated.

\section{MATERIALS AND METHODS}

\subsection{Plant material}

\subsubsection{Phytotron-grown material}

Six barley genotypes representing large inherited differences in both extract viscosity and $\beta$-glucan contents (Table I) were selected for this study. Duplicate sets of plants were grown in the phytotron at the Royal College of Forestry, Stockholm under conditions giving excellent vegetative growth for eight weeks, that is, until approx. seven spikes had emerged. Thereafter, one set of plants was rained upon. In all other respects the two sets of plants were treated identically; for example, with respect to the amount of water passing through the soil. Flour obtained from whole grains or pure endosperms was analysed for viscosity of the acid flour extract as well as its soluble, insoluble and total $\beta$-glucan content. The term soluble $\beta$-glucans represents the $\beta$-glucans of the acid flour extract and is not equal to all the $\beta$-glucans that might be made soluble at higher temperatures ( 1 ) or by the recently described $\beta$-glucan solubilising enzyme (2).

\subsubsection{Field-grown material}

Samples from the three commercial varieties of barley Nordal, Lofa and Lami were received from various areas of Denmark.

\subsection{Phytotron conditions}

A description of the phytotron and the methods used to cultivate barley are found in references $(11,18)$. The environmental conditions used in the present experiment are summarised in Figure 1 and described more fully below.

Table I

Viscosity of acid flour extracts and contents of total and soluble $\beta$-glucans from six barley genotypes grown in Denmark in 1976 and in New Zealand in 1977/78a.

\begin{tabular}{lcccc}
\hline & \multicolumn{2}{c}{$\begin{array}{c}\text { Viscosity of acid flour } \\
\text { extract (cP) }\end{array}$} & 1978 & \multicolumn{2}{c}{$\begin{array}{c}\text { B-glucan }(\% \text { of dry flour) } \\
\text { Total } \\
\text { Genotype }\end{array}$} & 1976 & 12 & 1978 & 1978 \\
\hline Triumph & 3.8 & - & 4.44 & 0.67 \\
Nordal & 12 & 256 & - & - \\
Lami & 68 & 632 & 5.22 & 1.84 \\
Minerva & 210 & 97 & 6.36 & 2.34 \\
$1352^{b}$ & 980 & 1.8 & 4.72 & 1.53 \\
$1392^{c}$ & 1.5 & & 2.00 & 0.14 \\
\hline
\end{tabular}

a Data from Aastrup (1).

b Genotypes containing the allele of the high lysine gene from Rise 1508 called lys-3a ( 12$)$.

c Genotypes containing the allele of the high lysine gene from Hiproly called lys $(12,14)$. 


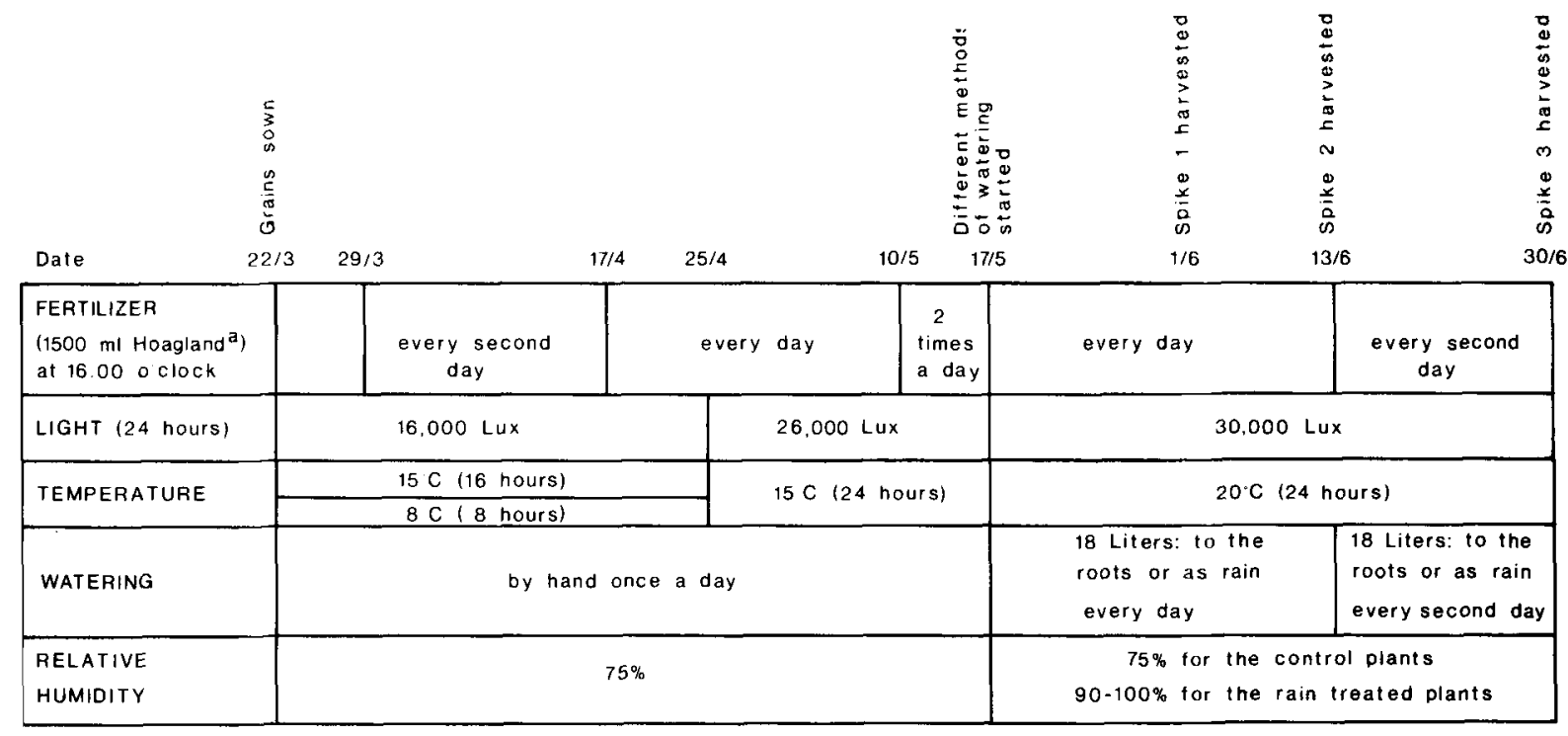

Figure 1. Time table for the phytotron conditions during the growth period of six barley genotypes having water supplied to the roots (control plants) or as rain (rain treated plants). 1a) The Hoagland solution contained in mg per ml: $100 \mathrm{NO}_{3}, 117.3 \mathrm{~K}, 14.7 \mathrm{P}, 95.4 \mathrm{Ca}, 23.2 \mathrm{Mg}, 31.9 \mathrm{~S}$ and $0.234 \mathrm{~B}, 2.18 \mathrm{Fe}, 0.24 \mathrm{Mn}, 0.017 \mathrm{Mo}, 0.0095$ $\mathrm{Cu}, 0.024 \mathrm{Zu}$. 
Seeds were planted in pots containing a mixture of fine gravel, medium sand and perlite in the volumetric proportions 2:1:0.75. The seedlings were thinned to one per pot. Three pots each of Nordal and Lami and two pots each of the remaining four genotypes were placed on two phytotron trucks. Plants on both trucks were grown under identical conditions (Figure 1) until eight weeks after sowing by which time approx. seven spikes had emerged from their leaf sheaths on all plants. These environmental conditions have been shown to result in excellent vegetative growth (6). Thereafter the two trucks were treated differently with respect to the method of watering.

For 29 days $70 \mathrm{~mm}$ of water was sprayed over the rain-truck each day. The water passing through the pots was collected and measured; the total being approximately $18 \mathrm{l} /$ day. The plants on the control-truck (Figure $2 \mathrm{~A}$ ) received water

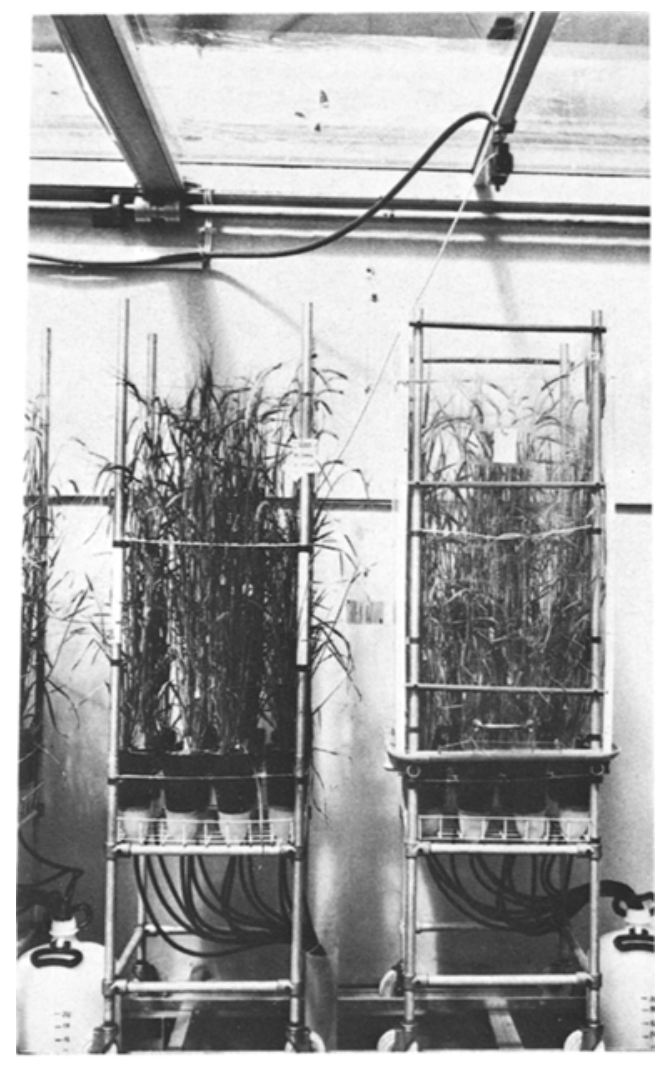

A

B

Figure 2. Phytotron trucks with six barley genotypes having water supplied to the roots (A) or as rain (B). from capillary tubes which dropped the water directly onto the soil. The total amount dropped was equivalent to that collected the previous day from the rain-truck. From the thirtieth day to the final harvesting at 46 days, the frequency of the watering (but not the amount) was reduced to every other day. The total volume of rain delivered was $2590 \mathrm{~mm}$ which is equivalent to 6 times the maximum total amount of rain (407 $\mathrm{mm}$ ) that fell during a growing season at Risø, Denmark and Svalöf, Sweden during the ten year period 1959 to 1968 . The watering took place over two six-hour periods, namely 6.30 to 12.30 and 18.30 to 00.30 . The water from the capillary tubes was dropped onto the soil in 5 sec. pulses of running water, followed by approx. 50 sec. pauses, while the rain was delivered through a nossel in $2 \mathrm{sec}$. pulses followed by approx. $50 \mathrm{sec}$. pauses. The nossel (Figure 2B) was located far enough above the rain truck to ensure that all 14 plants were equally exposed to the rain.

A second difference between the control- and the rain-truck was that the rain-truck was enclosed on the sides by plexi-glass from the level of the bottom of the pots to the tips of the ripe spikes (Figure 2B). Previous experiments have shown that under the standard phytotron watering conditions, enclosing the sides of a truck with plexi-glass does not affect the 1000 grain weight (I. DormLing \& P. voN WetTSTEINKNOWLES, unpublished). In the present experiments the plants on the rain-truck were exposed to a higher relative humidity than those on the control-trucks. Earlier measurements (I. DoRMLING and P. VON WeTtSTEIN-KNOWLES) on heading plants had demonstrated that the relative humidity on a control-truck was $75 \%$. On an unenclosed rain-truck, the relative humidity decreased from 100 to $90 \%$ in the six hours following the end of the rain. Thus, in the present experiment in which the sides of the raintruck were enclosed, the relative humidity was certainly greater than $90 \%$ at all times. Light and temperature regimes are as given in Figure 1.

\subsection{Harvesting}

The spikes were marked on the day of ear emergence. Spike 1 was harvested at green 
Table II

Extract viscosity, $\beta$-glucan content, \% dry weight and 1000 grain weight of grains matured in the presence or absence of rain and harvested at different stages of ripeness from plants of six barley genotypes.

\begin{tabular}{|c|c|c|c|c|c|c|c|c|c|}
\hline $\begin{array}{l}\text { Geno- } \\
\text { type }\end{array}$ & Spike $^{\text {a }}$ & $\begin{array}{l}\text { Days after } \\
\text { spike } \\
\text { emergence }\end{array}$ & $\begin{array}{l}\% \text { dry } \\
\text { weight }\end{array}$ & $\begin{array}{c}1000 \\
\text { grain } \\
\text { weight } \\
(\mathrm{g})\end{array}$ & $\begin{array}{l}\text { Visco- } \\
\text { sity of } \\
\text { extract } \\
\text { (cP) }\end{array}$ & $\begin{array}{c}\beta \\
\text { soluble } \\
(\%)\end{array}$ & $\begin{array}{l}\text { Ican cont } \\
\text { insoluble } \\
(\%)\end{array}$ & total & $\begin{array}{c}\text { g } \beta \text {-glucan } / \\
\text { grain }\end{array}$ \\
\hline 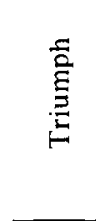 & $\begin{array}{l}1- \\
1+ \\
2- \\
2+ \\
3- \\
3+\end{array}$ & $\begin{array}{l}30 \\
28 \\
39 \\
35 \\
56 \\
54 \\
\end{array}$ & $\begin{array}{l}34.4 \\
31.7 \\
87.7 \\
48.1 \\
90.3 \\
90.0\end{array}$ & $\begin{array}{l}31.4 \\
30.5 \\
40.9 \\
33.6 \\
43.7 \\
37.6 \\
\end{array}$ & $\begin{array}{c}8.0 \\
7.2 \\
11 \\
3.3 \\
6.6 \\
1.9\end{array}$ & $\begin{array}{l}1.16 \\
0.61 \\
1.05 \\
0.74 \\
1.05 \\
0.50\end{array}$ & $\begin{array}{l}3.97 \\
2.31 \\
3.17 \\
2.28 \\
4.12 \\
2.49\end{array}$ & $\begin{array}{l}5.13 \\
2.92 \\
4.22 \\
3.02 \\
5.17 \\
2.99\end{array}$ & $\begin{array}{l}0.161 \\
0.089 \\
0.173 \\
0.102 \\
0.226 \\
0.112\end{array}$ \\
\hline 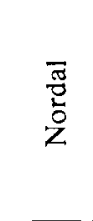 & $\begin{array}{l}1- \\
1+ \\
2- \\
2+ \\
3- \\
3+\end{array}$ & $\begin{array}{l}30 \\
30 \\
38 \\
37 \\
55 \\
52\end{array}$ & $\begin{array}{l}32.6 \\
32.9 \\
60.3 \\
57.4 \\
91.3 \\
90.8\end{array}$ & $\begin{array}{l}36.8 \\
25.1 \\
58.0 \\
52.7 \\
59.9 \\
46.8\end{array}$ & $\begin{array}{c}22 \\
4.8 \\
15 \\
3.2 \\
9.9 \\
2.7\end{array}$ & $\begin{array}{l}1.69 \\
1.18 \\
1.64 \\
1.03 \\
1.19 \\
0.73\end{array}$ & $\begin{array}{l}2.17 \\
3.05 \\
3.62 \\
2.95 \\
3.74 \\
2.29\end{array}$ & $\begin{array}{l}3.86 \\
4.23 \\
5.26 \\
3.98 \\
4.93 \\
3.02\end{array}$ & $\begin{array}{l}0.142 \\
0.106 \\
0.305 \\
0.210 \\
0.295 \\
0.141\end{array}$ \\
\hline 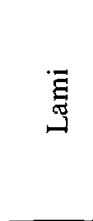 & $\begin{array}{l}1- \\
1+ \\
2- \\
2+ \\
3- \\
3+\end{array}$ & $\begin{array}{l}29 \\
30 \\
39 \\
40 \\
56 \\
54\end{array}$ & $\begin{array}{l}38.3 \\
30.1 \\
66.3 \\
48.1 \\
91.6 \\
90.1\end{array}$ & $\begin{array}{l}45.0 \\
34.0 \\
64.1 \\
45.1 \\
59.5 \\
43.3\end{array}$ & $\begin{array}{l}31 \\
26 \\
84 \\
10 \\
16 \\
5.0\end{array}$ & $\begin{array}{l}1.50 \\
1.60 \\
2.25 \\
1.14 \\
1.19 \\
0.85\end{array}$ & $\begin{array}{l}2.87 \\
1.71 \\
3.83 \\
4.46 \\
4.55 \\
2.90\end{array}$ & $\begin{array}{l}4.37 \\
3.31 \\
6.08 \\
5.60 \\
5.74 \\
3.75\end{array}$ & $\begin{array}{l}0.197 \\
0.113 \\
0.390 \\
0.253 \\
0.342 \\
0.162\end{array}$ \\
\hline & $\begin{array}{l}1- \\
1+ \\
2- \\
2+ \\
3- \\
3+\end{array}$ & $\begin{array}{l}32 \\
30 \\
37 \\
36 \\
56 \\
52\end{array}$ & $\begin{array}{l}35.7 \\
31.6 \\
58.7 \\
57.4 \\
91.4 \\
90.9\end{array}$ & $\begin{array}{l}41.5 \\
34.2 \\
59.6 \\
44.9 \\
59.6 \\
48.6\end{array}$ & $\begin{array}{r}46 \\
79 \\
430 \\
160 \\
220 \\
27\end{array}$ & $\begin{array}{l}2.42 \\
2.62 \\
2.89 \\
2.88 \\
2.38 \\
1.95\end{array}$ & $\begin{array}{l}2.92 \\
2.62 \\
3.74 \\
3.51 \\
4.10 \\
3.82\end{array}$ & $\begin{array}{l}5.34 \\
5.24 \\
6.63 \\
6.39 \\
6.48 \\
5.77\end{array}$ & $\begin{array}{l}0.222 \\
0.179 \\
0.395 \\
0.287 \\
0.386 \\
0.280\end{array}$ \\
\hline $\begin{array}{l}\overparen{n} \\
\stackrel{\Xi}{2} \\
n \\
n \\
2\end{array}$ & $\begin{array}{l}1- \\
1+ \\
2- \\
2+ \\
3- \\
3+\end{array}$ & $\begin{array}{l}31 \\
29 \\
38 \\
36 \\
57 \\
54\end{array}$ & $\begin{array}{l}30.0 \\
28.6 \\
56.2 \\
59.1 \\
90.2 \\
89.7\end{array}$ & $\begin{array}{l}30.8 \\
29.1 \\
52.3 \\
41.7 \\
51.9 \\
41.8\end{array}$ & $\begin{array}{r}150 \\
180 \\
1300 \\
860 \\
98 \\
44\end{array}$ & $\begin{array}{l}1.55 \\
2.16 \\
2.73 \\
2.62 \\
2.27 \\
2.15\end{array}$ & $\begin{array}{l}2.98 \\
2.77 \\
5.56 \\
4.17 \\
4.54 \\
4.58\end{array}$ & $\begin{array}{l}4.53 \\
4.93 \\
8.29 \\
6.79 \\
6.81 \\
6.73\end{array}$ & $\begin{array}{l}0.140 \\
0.143 \\
0.434 \\
0.283 \\
0.353 \\
0.281\end{array}$ \\
\hline 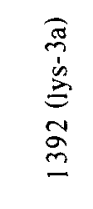 & $\begin{array}{l}1- \\
1+ \\
2- \\
2+ \\
3- \\
3+\end{array}$ & $\begin{array}{l}30 \\
27 \\
38 \\
33 \\
57 \\
53\end{array}$ & $\begin{array}{l}24.6 \\
26.2 \\
50.0 \\
56.8 \\
89.4 \\
88.7\end{array}$ & $\begin{array}{l}31.8 \\
28.6 \\
45.6 \\
40.8 \\
41.9 \\
39.7\end{array}$ & $\begin{array}{l}2.9 \\
2.6 \\
2.0 \\
1.6 \\
1.6 \\
1.2\end{array}$ & $\begin{array}{l}0.31 \\
0.38 \\
0.42 \\
0.21 \\
0.56 \\
0.16\end{array}$ & $\begin{array}{l}3.02 \\
2.06 \\
2.04 \\
2.44 \\
1.94 \\
1.77\end{array}$ & $\begin{array}{l}3.33 \\
2.44 \\
2.46 \\
2.65 \\
2.50 \\
1.93\end{array}$ & $\begin{array}{l}0.106 \\
0.070 \\
0.112 \\
0.108 \\
0.104 \\
0.077\end{array}$ \\
\hline
\end{tabular}

a +: Rain treated plants. -: Control plants. Spikes harvested at 1, green ripeness; 2, yellow ripeness; 3, full ripeness. (See Figure 1).

b \% of dry flour.

ripeness (approx. 30\% dry weight) about 30 days after ear emergence, spike 2 at yellow ripeness (approx. $60 \%$ dry weight) 37 days after ear emergence and spike 3 at full ripeness (approx. 90\% dry weight) (Table II, columns 2 and 3). Four grains (no. 2 and no. 6 in each row) 
were immediately frozen for later enzyme determination. Two grains (no. 5 in each row) were taken for dry weight determinations, and the remaining grains were boiled in $80 \%$ ethanol for $30 \mathrm{~min}$ to destroy possible enzyme activity. All results concerning whole grains (Table II) are from one plant of each genotype. For the pure endosperm analysis four grains (no. 2 and 6 in each row) of the second plant were used. The results from the two plants of each genotype were used for the variance analysis of the dry weights and the 1000 grain weights.

\subsection{Dry weight and 1000 grain weight determinations}

The wet weight was determined by immediate weighing of the two grains from each plant, and the dry weight ascertained by weighing the grains again after two hours in an oven at 100 ${ }^{\circ} \mathrm{C}$ and $30 \mathrm{~min}$ in a dessicator. The dry weight is expressed as percentage of wet weight ( $\%$ dry weight). The combined weight of the two grains from each plant multiplied by 500 gives the 1000 grain weight.

\subsection{Viscosity determinations}

The preparation of the acid flour extract from whole grains and the viscosity determinations were carried out by the basic method, using $0.2 \mathrm{~g}$ of flour, as described by AAsTrup (1), with the exception that the grains were boiled in $80 \%$ ethanol for $30 \mathrm{~min}$ to destroy any glucanase activity followed by drying on filter paper for a week before grinding. To obtain flour from pure endosperm, grains were dehulled by gentle pearling and polishing with sand paper. Thereafter the pure endosperm was ground in a ball mill. The standard error of the viscosity determinations is less than $4 \%(1)$.

\section{6. $\beta$-glucan determinations}

The total, the soluble and in the case of the pure endosperm the insoluble $\beta$-glucan contents were determined as described earlier (1). The standard error is less than $4 \%$ (1).

\subsection{Endo- $\beta$-glucanase determinations}

The enzyme was measured by modifications of the method described by Preece and Aitken (15), where the $\beta$-glucanase activity is expressed in terms of change in reciprocal viscosity per min per unit of material. The modifications were developed in collaboration with G. D. Coles: The substrate was a $0.5 \%$ barley $\beta$-glucan in 0.08 m-acetate buffer, $\mathrm{pH} 4.75$. A $15 \%(\mathrm{w} / \mathrm{v})$ suspension of flour in an extraction medium consisting of $0.1 \mathrm{M}-\mathrm{NaCl}, 7.5 \mathrm{~mm}^{-\mathrm{NaN}_{3}, 5.0}$ mM-ethylene diamine tetra-acetic acid (EDTA), $5.0 \mathrm{~mm}$-ascorbic acid and $2.0 \mathrm{~mm}$-dithiotreitole (DTT) was made. The enzyme extract was obtained by shaking the suspension for $30 \mathrm{~min}$ at room temperature, centrifuging at $25,000 \mathrm{~g}$ for ten min and filtering the supernatant through a glass fiber disc. A $1 \mathrm{ml}$ aliquot of the $\beta$-glucan substrate solution was placed in the cup of a viscometer (1) and allowed to equilibrate at 30 ${ }^{\circ} \mathrm{C}$. The instrument was then briefly shut down, $0.1 \mathrm{ml}$ of the flour enzyme extract added and the viscometer restarted. The rate of the reaction was monitored on a chart recorder. From the resulting curve the reciprocal viscosity and the specific enzyme activity were determined.

\section{RESULTS}

\subsection{The effect of rain on $\%$ dry weight and 1000 grain weight}

As expected, the \% dry weight of the seeds increased significantly from the stage of green ripeness (spike 1) to yellow ripeness (spike 2) and again from the stage of yellow ripeness to full ripeness (spike 3) (Tables III and II, column 3). No significant difference was obtained for the \% dry weight of seeds from spikes 1,2 and 3 neither among the various genotypes nor among the methods of watering. The only exceptions to this generalization are the spikes harvested at yellow ripeness from Lami and Triumph where grains from the control plants had a much higher dry weight percentage than the grains from the rain treated plants.

The 1000 grain weight also varies significantly with respect to the time of harvest (Table III). Unlike the \% dry weight, however, the increase is highly significant from green to yellow ripeness (paired t-test: $t=7.84^{* * *}$ ), but not from yellow to full ripeness $\left(t=0.45^{\text {n.s. }}\right)$ 
Table III

Variance analysis of the $\%$ dry weight and 1000 grain weight of six barley genotypes having water supplied to the roots or as rain and harvested at three different stages of ripeness.

\begin{tabular}{lcc}
\hline & \% dry weight & $\begin{array}{c}1000 \\
\text { grain weight }\end{array}$ \\
\hline Harvest time & $274^{* * *}$ & $60.0^{* * *}$ \\
Genotype & $1.23^{\text {n.s. }}$ & $15.2^{* * *}$ \\
Water supply & $3.00^{\text {n.s. }}$ & $38.4^{* *}$ \\
\hline${ }^{* *}: 99 \%$ significant level & \\
$* * *: 99.9 \%$ significant level \\
n.s.: Not significant
\end{tabular}

(Table II, columns 3 and 4). The genotype also plays a significant role in determining the 1000 grain weight (Table III). From Table II, column 4 it is seen that Minerva, Lami and Nordal have larger grains than the other three genotypes. In addition, the method of watering significantly influences the 1000 grain weight (Table III). The grains from the rain treated plants were consistently smaller than those from the control plants (Table II, column 4).

\subsection{The effect of rain on extract viscosity and $\beta$-glucan content}

A comparison of the extract viscosities obtained for grains of control plants versus rain treated plants (Table II, column 5) reveals that up to the stage of green ripeness (spike 1), this parameter is not consistently affected by the method of watering $\left(t=0.63^{\text {n.s. }}\right)$. In Minerva and 1352 the grains from the rain treated plants had the higher extract viscosity whereas in the other four genotypes the grains from the control plants had the greater extract viscosity. Only for the genotype Nordal is a marked difference seen. Similar non-significant differences between the grains from control and rain treated plants were obtained for the amounts of soluble $(\mathrm{t}=$ $\left.0.60^{\text {n.s. }}\right)$, insoluble $\left(\mathrm{t}=1.56^{\text {n.s. }}\right)$ and total $(\mathrm{t}=$ $1.41^{\text {n.s. }}$ ) -glucan (Table II, columns 6, 7 and 8 ).

At yellow ripeness (spike 2) the extract viscosities of grains from all rain treated plants were significantly less $\left(t=3.74^{*}\right)$ than those from the respective control plants (Table II, column 5). A similar trend is seen when the $\beta$ glucan contents are compared. The divergence, however, is smaller, and in the case of Minerva the $\beta$-glucan contents of the grains from the control and the rain treated plants were equal within standard error (Table II, columns 6,7 and 8). The paired t-test revealed that the difference was significant for the total $\beta$-glucan content $\left(\mathrm{t}=2.74^{*}\right)$, and just below the significant level $(t=2.57)$ for the soluble $\beta$ glucan content $\left(t=2.37^{\text {n.s. }}\right)$.

At full ripeness (spike 3) the extract viscosities of grains from all rain treated plants were again significantly lower $\left(\mathrm{t}=4.70^{* *}\right)$ than those obtained from the grains of the respective control plants (Table II, column 5). At this stage of growth the significant difference in the extract viscosity was paralleled by significant differences in soluble $\left(\mathrm{t}=6.41^{* *}\right)$, insoluble $\left(\mathrm{t}=2.63^{*}\right)$ and total $\left(t=3.41^{*}\right) \beta$-glucan content. The only exception is the genotype 1352 , having the lys allele, where the amount of $\beta$-glucan was equal in the grains from control and rain treated plants within standard error.

The gram $\beta$-glucan per grain was calculated from the 1000 grain weight and the total $\beta$ glucan content (Table II, column 9). Since both the 1000 grain weight and the percentage of $\beta$ glucan were affected similarly by the method of watering it is not surprising that the $\beta$-glucan per grain reveals a larger difference between the control and the rain treated plants than either variable did by itself. The difference was significant at yellow $\left(\mathrm{t}=4.37^{* *}\right)$ and full $(\mathrm{t}=$ $\left.4.84^{* *}\right)$ ripeness as well as at green ripeness $(t$ $=3.56^{*}$ ).

\subsection{The influence of harvest time on extract viscosity and $\beta$-glucan content}

Between the stages of green and yellow ripeness the extract viscosities from grains of control plants either increased (Triumph, Lami, Minerva, 1352) or decreased (Nordal, 1392) (Table II, column 5). Different extract viscosities were also observed between these stages for the grains from rain treated plants. No consistent relationship between the direction of the change for the two water treatments occurred. Nevertheless, the direction of change in extract viscos- 
ity is generally paralleled by that of the change in soluble $\beta$-glucan, and to some extent by that in insoluble and total $\beta$-glucan contents (Table II, columns 5, 6, 7 and 8). When the $\beta$-glucan content is calculated as grams per grain, however, a consistent increase from green to yellow ripeness is seen for both control plants and rain treated plants (Table II, column 9).

During the subsequent ripening period, that is, from yellow to full ripeness, a significant $(\mathrm{t}=$ $3.75^{* *}$ ) decrease in extract viscosity is paralleled by a significant $\left(\mathrm{t}=3.79^{* *}\right)$ decrease in soluble $\beta$-glucan (Table II, columns 5 and 6). However, no significant $\left(\mathrm{t}=0.36^{\text {n.s. }}\right)$ decrease of insoluble $\beta$-glucans occurred, and the general decrease in total $\beta$-glucan and gram $\beta$-glucan per grain obtained for all genotypes except Triumph were just below the significant level.

\subsection{Extract viscosity and $\beta$-glucan contents of pure endosperm at full ripeness}

Smaller 1000 grain weights were shown above (section 3.1 and 3.2) to be correlated with smaller extract viscosities and $\beta$-glucan contents.
One can envisage this relationship arising as follows: The $\beta$-glucans are mainly found in the endosperm (7). Thus, the percentage that the latter represents of the total grain will influence the gram $\beta$-glucan per grain measurements. In the present experiments the percentage of husk was found to be greater in all grains from rain treated plants (about 25\%) compared to those from control plants (about 19\%). Thus, the husk will have a greater dilution effect on the amount of $\beta$-glucan per grain in flour derived from the rain treated grains. In order to eliminate the diluting effect of the husk, $\beta$-glucan contents and extract viscosities were measured on pure endosperm. Measurements on both parameters gave higher values in the pure endosperm (Table IV) than in the respective whole grains (Table II). The single exception is the soluble $\beta$-glucan content of Minerva grains from rain treated plants, where the whole grain figure is the higher (Table II, column 5).

It was expected that the three genotypes having smaller grains (section 3.1.) would show a more marked increase in extract viscosity of endosperm flour compared to whole grain flour

\section{Table IV}

Viscosity of acid flour extracts and $\beta$-glucan contents of pure endosperm isolated from grains of control and rain treated plants of six barley genotypes harvested at full ripeness.

\begin{tabular}{|c|c|c|c|c|c|}
\hline Genotype & Rain & $\begin{array}{l}\text { Viscosity of } \\
\text { acid flour } \\
\text { extract (cP) }\end{array}$ & $\begin{array}{c}\text { Soluble } \\
\beta \text {-glucan } \\
\text { (\% of dry flour) }\end{array}$ & $\begin{array}{c}\text { Insoluble } \\
\beta \text {-glucan } \\
\text { (\% of dry flour) }\end{array}$ & $\begin{array}{c}\text { Totala } \\
\beta \text {-glucan } \\
\text { (\% of dry flour) }\end{array}$ \\
\hline Triumph & $\begin{array}{l}- \\
+\end{array}$ & $\begin{array}{l}52 \\
2.6\end{array}$ & $\begin{array}{l}1.29 \\
0.56\end{array}$ & $\begin{array}{l}3.62 \\
3.68\end{array}$ & $\begin{array}{l}4.91 \\
4.24\end{array}$ \\
\hline Nordal & + & $\begin{array}{l}21 \\
3.4\end{array}$ & $\begin{array}{l}1.27 \\
0.86\end{array}$ & $\begin{array}{l}5.57 \\
4.79\end{array}$ & $\begin{array}{l}7.02 \\
5.85\end{array}$ \\
\hline Lami & 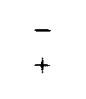 & $\begin{array}{r}494 \\
11\end{array}$ & $\begin{array}{l}2.43 \\
1.08\end{array}$ & $\begin{array}{l}5.74 \\
4.73\end{array}$ & $\begin{array}{l}8.17 \\
5.82\end{array}$ \\
\hline Minerva & $\begin{array}{l}- \\
+\end{array}$ & $\begin{array}{r}550 \\
38\end{array}$ & $\begin{array}{l}2.42 \\
1.34\end{array}$ & $\begin{array}{l}6.15 \\
5.51\end{array}$ & $\begin{array}{l}8.57 \\
6.85\end{array}$ \\
\hline 1352 (lys) & - & $\begin{array}{r}1070 \\
103\end{array}$ & $\begin{array}{l}2.80 \\
2.55\end{array}$ & $\begin{array}{l}5.40 \\
5.62\end{array}$ & $\begin{array}{l}8.20 \\
8.12\end{array}$ \\
\hline 1392 (lys-3a) & $\begin{array}{l}- \\
+\end{array}$ & $\begin{array}{l}1.4 \\
1.4\end{array}$ & $\begin{array}{l}0.44 \\
0.26\end{array}$ & $\begin{array}{l}2.53 \\
2.47\end{array}$ & $\begin{array}{l}2.97 \\
2.73\end{array}$ \\
\hline
\end{tabular}

a Sum of soluble and insoluble $\beta$-glucans. 
than the three genotypes with larger grains (section 3.1). For Triumph, 1352, Minerva and Nordal this expectation was realized. To determine the origin and/or possible significance of the unexpectedly large increase in the extract viscosity of the flour from endosperms compared to whole grains of Lami will require further experiments. Presumably in the case of 1392 having the lys-3a allele, the amount of $\beta$-glucan is so small that the absence of the husk had essentially no effect on the extract viscosity.

The difference in extract viscosity between grains from the respective control and rain treated plants appears numerically greater for the pure endosperm (Table IV) than for the whole grains (Table II). The paired t-test, however, does not reveal a greater significant difference for the extract viscosity $\left(\mathrm{t}=4.46^{* *}\right)$ than that obtained for the whole grain extract viscosities $(\mathrm{t}=$ $4.70^{* *}$ ). The lower extract viscosities of the endosperm flour from the rain treated grains are paralleled, as in the case of whole grains, by significant differences in soluble $\left(t=3.47^{*}\right)$ and total $\left(t=2.74^{*}\right) \beta$-glucan contents. Unlike for the whole grain analyses, however, the amount of insoluble $\beta$-glucans in the pure endosperm is not significantly altered by the rain treatment $(t$ $=1.78^{\text {n.s. }}$. In fact, within standard error the amount of insoluble $\beta$-glucans in the pure endosperm from control and rain treated plants of Triumph, 1352 and 1392 are equal. The endosperm analyses confirm the interesting observations from the whole grain analysis of 1352, which contains the lys allele. That is, a large difference in extract viscosity between the grains from control and rain treated plants, but no difference within standard error in the amount of soluble, insoluble or total $\beta$-glucans.

Thus, from the analyses of the pure endosperms it can be concluded that the observed differences in extract viscosity, soluble and total $\beta$-glucan contents are not mainly due to the differences in 1000 grain weight. Only the variation in the amount of the insoluble $\beta$ glucans can be attributed to differences in 1000 grain weight presumably brought about by the dilution effect.

\subsection{Structural nature of the soluble $\beta$-glucans}

A very good correlation has been shown to exist (1) between the viscosities of barley flour extracts and their $\beta$-glucan contents (the soluble $\beta$-glucans), given that the structural nature of the $\beta$-glucans are very similar in all the acid flour extracts investigated. Consequently, the slopes of the regression lines and the correlation coefficients between the in(extract viscosity) and the soluble $\beta$-glucan content of the grains from different stages of ripeness watered in different ways can be expected to indicate if the extracted $\beta$-glucans are structurally similar under all these conditions.

The genotype 1352 , having the lys allele, is omitted in the following discussion of the correlation between the extract viscosity and the soluble $\beta$-glucans, since the structure of the $\beta$ glucans in its acid flour extract appear to be different in grains from control and rain treated plants. This conclusion is based on the observed large difference in extract viscosity and equal amounts of $\beta$-glucans in grains from control and rain treated plants harvested at full ripeness.

Figure 3 shows the logarithmic relationship between the extract viscosity and the soluble $\beta$ glucan content of grains from spikes at the three

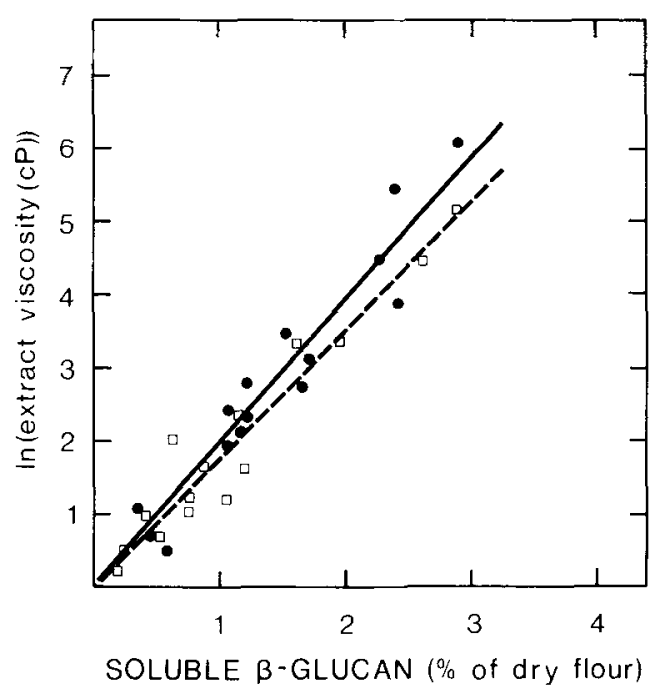

Figure 3. The logarithmic relationship between the viscosity of the acid flour extract and the soluble $\beta$ glucan content of grains from spikes at the three stages of ripeness harvested from control plants $(\Omega)$ and rain treated plants ( $([-\boxminus \square)$ ). 
stages of ripeness harvested from control and rain treated plants. The correlation coefficients found for the control plants $\left(R^{2}=0.92\right.$, S.E.E. $=0.49)$ and the rain treated plants $\left(R^{2}=0.93\right.$, S.E.E. $=0.40)$ are not as good as the correlation coefficient found earlier $\left(\mathbf{R}^{2}=0.99\right.$, S.E.E. $=$ $0.19)$ when relating extract viscosity to soluble $\beta$-glucan content of grains from 18 genotypes of barley harvested at full ripeness (1). This might indicate that the structural nature of the soluble $\beta$-glucans are not similar in all samples. Firstly, the effect of water treatment can be examined. The regression lines (Figure 3) obtained for the grains of control plants and rain treated plants were not significantly different $\left(t=1.66^{\text {n.s. }}\right)$. This means that the water treatment had no influence on the structural nature of the $\beta$ glucans. Secondly, the possible influence of the stages of ripeness can be studied. Figure 4 shows the logarithmic relationship between the extract viscosity and the soluble $\beta$-glucan content at the three stages of ripeness. Compared to the correlation coefficients of the regression lines in Figure 3 the correlation coefficients are better for yellow ripeness $\left(R^{2}=0.96\right.$, S.E.E. $\left.=0.43\right)$ and full ripeness $\left(\mathrm{R}^{2}=0.95\right.$, S.E.E. $\left.=0.39\right)$ but less good for green ripeness $\left(\mathrm{R}^{2}=0.88\right.$, S.E.E. $=0.43)$. This implies that the largest difference

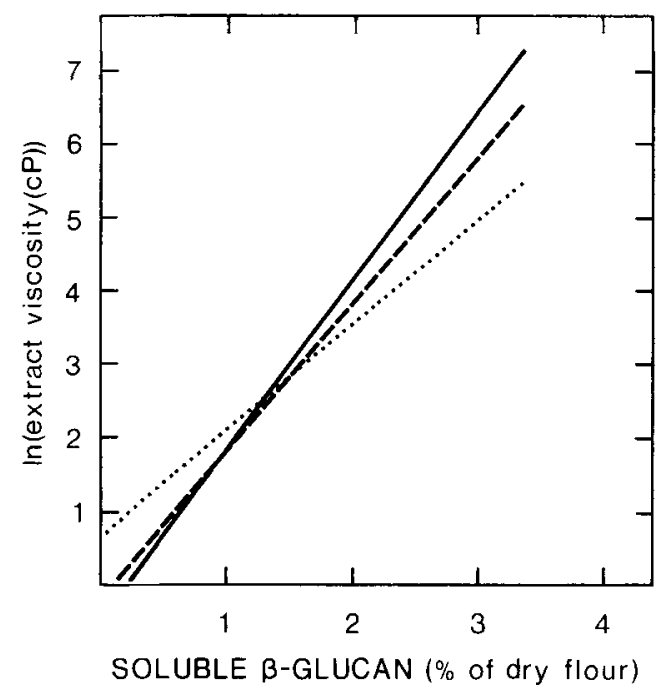

Figure 4. The logarithmic relationship between the viscosity of the acid flour extract and the soluble $\beta$ glucan content in grains from control and rain treated plants of green ripe spikes (....), yellow ripe spikes $(--)$ and fully ripe spikes (- in structural nature of the $\beta$-glucans occurs at green ripeness. A comparison of the regression lines derived from the grains of yellow ripeness and full ripeness showed no significant difference $\left(t=0.33^{n . s}\right)$. The slopes obtained for the grains of green ripeness and yellow ripeness, however, were significantly different $\left(t=2.34^{*}\right)$. Thus, the soluble $\beta$-glucans in grains harvested at green ripeness possibly have a different structure compared to the $\beta$-glucans in grains harvested at yellow and full ripeness.

\subsection{Endo- $\beta$-glucanase activity}

Extracts were made as described in Material and Methods. In the controls a malt extract or distilled water was substituted for the barley extract. The malt extract showed a specific enzyme activity of 16 units of reciprocal viscosity $\cdot \mathrm{g}^{-1} \cdot \mathrm{min}^{-1}$. The distilled water showed no activity, and all the barley extracts had activities which were about $0.1 \%$ of that of the malt extract.

\section{DISCUSSION}

\subsection{Phytotron results compared to field results}

Is it possible to relate the results from a phytotron, where all the growing conditions are controlled to field results, where none of the growing conditions are controlled?

From different areas of Denmark (Figure 5) a number of samples of the barley varieties Lami, Lofa and Nordal were collected. In Table V the extract viscosities obtained for each area are listed with the respective temperature, precipitation and relative humidity means in July and August of 1977. Most interestingly, the samples with the lowest extract viscosities came from Lolland-Falster (area 9) where the highest mean temperature, precipitation and relative humidity measurements were recorded. Barley grown in this part of Denmark has been prefered for many years by the malters.

The following interesting set of comparisons can be made between the present field and phytotron results. The range in extract viscosities are greater for the field study (Table V) than in the phytotron study (Table II, column 5). In the phytotron the temperature and the amount of water given to the plants were the same for both 


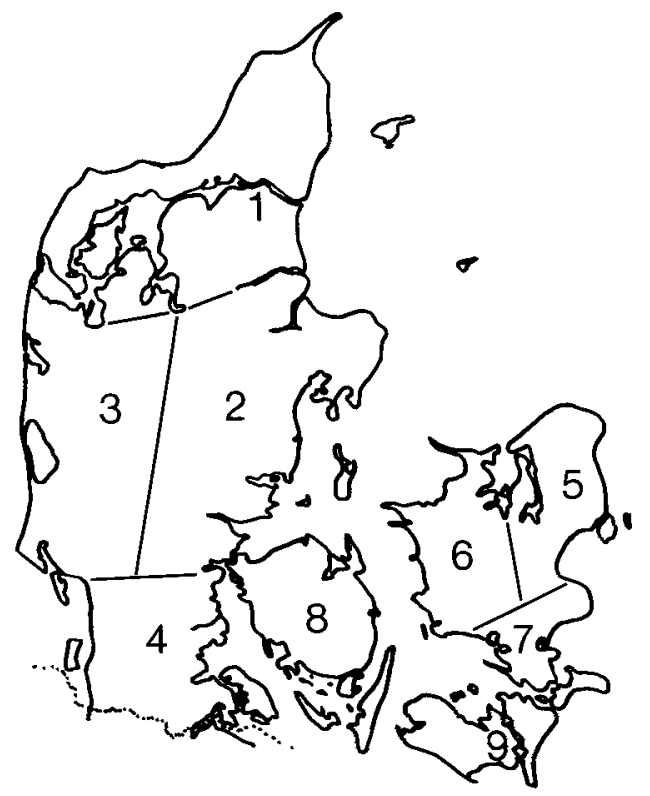

Figure 5. Areas of Denmark from which grains of three varieties have been harvested in 1977 and analysed for their extract viscosities. See Table V.

control and rain treated plants, but the rain treated plants were wet half of the time and surrounded by air of high relative humidity.
Furthermore the grains of these plants were significantly smaller than those of the control plants. In the field where the temperature, precipitation and relative humidity varied, the 1000 grain weights were remarkably similar $(42$ to $44 \mathrm{~g}$ ) for grains from all studied areas.

Although the field material is limited, a tendency towards a correlation is apparent between the extract viscosities of Nordal and the environmental parameters. The extract viscosity was found to be negatively correlated to the precipitation $\left(\mathbf{R}^{2}=0.80^{* * *}\right.$, S.E.E. $\left.=0.37\right)$ and the relative humidity $\left(R^{2}=0.55^{*}\right.$, S.E.E. $=0.55)$ in August. It is notable, however, that the relative humidity and the precipitation in August had a very low correlation coefficient $\left(R^{2}\right.$ $=0.21^{\text {n.s.). }}$ This result indicates that the extract viscosity and thus the soluble $\beta$-glucan content are independently affected during the later stages of ripening by both precipitation, as earlier shown by SMART (17), and relative humidity, as shown in the present phytotron study. However, there seems to be a difference in extract viscosity between samples from Jutland and Sealand which is not due to either precipitation or relative humidity. This observation suggests that at least one other environmental factor may be

\section{Table V}

Mean temperature, precipitation and relative humidity in July and August 1977 obtained from eight areas ${ }^{2}$ of Denmark, and the respective mean extract viscosities for grains of Lami, Lofa and Nordalb.

\begin{tabular}{|c|c|c|c|c|c|c|c|c|c|}
\hline & \multicolumn{2}{|c|}{$\begin{array}{c}\text { Temperature } \\
\left({ }^{\circ} \mathrm{C}\right)\end{array}$} & \multicolumn{2}{|c|}{$\begin{array}{l}\text { Precipitation } \\
\quad(\mathrm{mm})\end{array}$} & \multicolumn{2}{|c|}{$\begin{array}{c}\text { Relative } \\
\text { humidity (\%) }\end{array}$} & \multicolumn{3}{|c|}{$\begin{array}{c}\text { Extract viscosity } \\
(\mathrm{cP})\end{array}$} \\
\hline & July & Aug. & July & Aug. & July & Aug. & Nordal & Lofa & Lami \\
\hline 1 Northern Jutland & 14.8 & 14.9 & 57.3 & 20.5 & 76.3 & 77.0 & 26 & 14 & 64 \\
\hline 2 Eastern Jutland & 15.2 & 15.1 & 52.7 & 30.1 & 77.3 & 78.9 & 12 & - & 130 \\
\hline 3 Western Jutland & 14.9 & 14.9 & 59.5 & 31.9 & 77.9 & 80.3 & 5.8 & 7.0 & 22 \\
\hline 5 Eastern Sealand & 15.7 & 15.6 & 76.9 & 34.9 & 75.8 & 76.3 & 12 & - & 140 \\
\hline 6 Western Sealand & 15.6 & 15.4 & 62.9 & 59.3 & 74.7 & 78.7 & 7.1 & - & - \\
\hline 7 Southern Sealand & 15.6 & 15.8 & 56.0 & 59.8 & 76.8 & 79.0 & 5.5 & - & - \\
\hline 8 Funen & 15.7 & 15.7 & 57.7 & 76.8 & 76.8 & 79.0 & 3.2 & 5.1 & - \\
\hline 9 Lolland-Falster & 15.8 & 15.8 & 63.5 & 84.3 & 79.6 & 80.1 & 2.5 & 2.7 & 8.1 \\
\hline
\end{tabular}

a Area 4, Southern Jutland, is not included as no samples were obtained from this area. (See Figure 6).

b The temperature, precipitation and relative humidity measurements are taken from the annual report of the Meteorological Institute of Copenhagen. 
very important in determining the soluble $\beta$ glucan content of the grains, e.g. soil type (17).These comparisons illustrate very clearly how difficult it is to draw a firm conclusion from the field data. Only by studying each of the environmental parameters individually and in various combinations under the controlled conditions of the phytotron will it be possible to fully understand the environmental contribution to $\beta$-glucan formation in barley grains.

\subsection{Rain effect}

It is evident from both the whole grain and the endosperm analyses of the phytotron grown material that the rain treated grains of the commercial varieties Minerva, Lami, Nordal and Triumph have lower extract viscosities and amounts of soluble and total $\beta$-glucans. A number of ways can be envisaged in which the rain effect is brought about: 1) Degradation of the $\beta$-glucans. If any marked degradation had taken place a range of smaller $\beta$-glucans would occur in the acid flour extract giving rise to lower extract viscosity. However, no marked difference was observed in the structural nature of the $\beta$ glucans between control and rain treated plants. Furthermore, negligible endo- $\beta$-glucanase activity was detected in the different treated grains. This implies that the observed decreases are not due to break down of the soluble $\beta$-glucans. 2) Lower synthesis of $\beta$-glucans. This is a reasonable explanation since the total $\beta$-glucan content is significantly lower in rain treated grains at both yellow and full ripeness. The conclusion is supported by the recent findings of Coles (5), who analysed grains from control and rain treated plants at six stages during the ripening period and in all cases found a lower content in the rain treated grains. 3) Modification of the $\beta$ glucans to give polymers inaccessible to the $\beta$ glucanase used for the $\beta$-glucan determinations, as suggested by CoLes (5). 4) Leaching of the glucose, a precursor of $\beta$-glucans, from the flag leaf and awns. These two organs have been shown to be to a considerable extent responsible for synthesis of the metabolites found in the grains of barley (9). Leaching of sugars from leaves has been shown by Morgan \& TUKEY (13).
When the whole grain analyses are considered, the same, albeit a much smaller, rain effect is seen between the appropriate grains from the high lysine genotype 1392 having the lys-3a allele from Risø 1508. In the endosperm analyses, however, the $\beta$-glucan contents and extract viscosity are not influenced by the rain. These results may simply reflect that it is not possible to reduce the $\beta$-glucan contents of barley grains below a given level. This level is apparently equivalent to the amount of $\beta$-glucans synthesised by 1392 .

The other high lysine genotype, 1352 having the lys allele from Hiproly, is also very interesting in that it has the same high amount of $\beta$-glucans both in the presence or absence of the rain. However, the extract viscosities of the rain treated grains are greatly reduced compared to extract viscosities of grains from the control plants. While a number of interesting speculations can be presented to explain this unexpected result, such as smaller or differently structured $\beta$-glucan molecules, it is felt that additional investigations should be made first.

\subsection{Ripening effect}

The $\beta$-glucans from grains harvested at green ripeness seems to be structurally different from the $\beta$-glucans harvested at yellow and full ripeness. This probably reflects the fact that at this stage of growth a high proportion of the $\beta$ glucans are in an early stage of synthesis where they have lower molecular weights and/or a different ratio of $\left(1-3^{\prime}\right)$ to (1-4') linkages. The latter is known for non-endospermic $\beta$-glucans in developing oat plants (3).

From yellow to full ripeness a significant decrease in extract viscosity is observed in agreement with earlier studies by GoHL (10). The decrease is paralleled by a significant decrease in amount of soluble $\beta$-glucans, but not by a significant decrease in insoluble $\beta$-glucans. The structural nature of the soluble $\beta$-glucans in grains from yellow and full ripeness was not found to be significantly different. Thus, it can be concluded that the decrease in extract viscosity is due to a lower percentage of soluble $\beta$-glucans in the acid flour extract and not to a degradation of the soluble $\beta$-glucans. Possible explanations for 
the observed decreased amounts of soluble $\beta$ glucans are the following: 1) Continued synthesis of non- $\beta$-glucans and no new synthesis of $\beta$ glucans would reduce the percentage of $\beta$ glucans. This is unlikely, however, because no increase was found in the 1000 grain weight between these two stages. 2) The soluble $\beta$ glucans become insoluble. In the present study no significant increases in the insoluble $\beta$ glucans were observed although an increase did occur in several cases, especially for the control plants. 3) A modification of the $\beta$-glucan structure so that the resulting polymers are inaccessible to the $\beta$-glucanase used for $\beta$-glucan determinations. Such a mechanism predicts a decrease in total $\beta$-glucan and gram $\beta$-glucan per grain. While such a decrease was seen in the present study, it was not statistically significant.

\section{ACKNOWLEDGEMENTS}

It is a pleasure to acknowledge professor Diter von Wettstein and Dr. PenNy von WettSTEIN-KNOWLES for inspiring discussions concerning the set up of the present experiments. I am most grateful for the help and encouragement provided by Dr. LaRS MUNCK through fruitful guidance and discussions, and to PenNy vON WETTSTEIN-KNOWLES for valuable help in preparing this communication. I wish to thank MAJ-BRITT NiELSEN for her excellent technical assistance and the personnel of the phytotron of the Royal College of Forestry, Stockholm, Sweden, for growing the plants.

\section{REFERENCES}

1. Aastrup, S.: The relationship between the viscosity of an acid flour extract of barley and its $\beta$-glucan content. Carlsberg Res. Commun. 44, 289-304 (1979)

2. Bamforth, C. W., H. L. Martin \& T. WainWRIGHT: A role for carboxypeptidase in the solubilization of barley $\beta$-glucan. J. Inst. Brew. (in press) (1979)

3. Buchala, A. J. \& K. C. B. Wilkie: The ratio of $\beta(1-3)$ to $\beta(1-4)$ glucosidic linkages in nonendospermic hemicellulosic $\beta$-glucans from oat plant (Avena sativa) tissues at different stages of maturity. Phytochemistry 10, 2287-2291 (1971)

4. Clarke, A. E. \& B. A. Stone: Chemistry and biochemistry of 1-3-glucans. Rev. Pure Appl. Chem. 13, 134-156 (1963)

5. Coles, G. D.: Accumulation of free sugars and glucosan in developing barley kernels. Carlsberg Res. Commun. 44, 439-453 (1979)

6. Durmling, I., A. Gustafsson, H. R. Jung \& D von Wettstein: Phytotron cultivation of Svalöf's Bonus barley and its mutant Svalöfs Mari. Heriditas 56, 221-237 (1966)

7. Fincher, G. B.: Morphology and chemical composition of barley endosperm cell walls. J. Inst. Brew. 81, 116-122 (1975)

8. Forrest, I. S. \& T. WAINWRIGHT: The mode of binding of $\beta$-glucans and pentosans in barley endosperm cell walls. J. Inst. Brew. 83, 279-286 (1977)

9. Frey-Wyssling, V. \& M. A. Vuttrose: Photosynthesis in the ear of barley. Nature 184, 20312032 (1959)

10. GоHL, B.: Influence of water-treatment of barley on the digestion process in rats. Z. Tierphysiol. Tierernaehr. Futtermittelkd. 39, 57-67 (1977)

11. Gustafsson, A.: Skoghögskolans fytotronanläggning. (The phytotron of the Royal College of Forestry.) Trävaruindustrien 50. 20, 433-439 (1965)

12. Jensen, J. \& H. Doll: Gene symbols for barley high-lysine mutants. Barley Genetics Newsletter 9, 33-37 (1979)

13. Morgan, J. V.\& H. B. Tukey, Jr.: Characterization of leachate from plant foliage. Plant Physiol. 39, 590-593 (1964)

14. Munck, L: : High lysine barley - a summary of the present research development in Sweden. Barley Genetics Newsletter 2, 54-59 (1972)

15. Preece, I. A. \& R. A. Aitken: Non-starchy polysaccharides of cerial grains IV. Cellulase activity and autolysis relationships of some malting barleys. J. Inst. Brew. 59, 453-461 (1953)

16. Preece, I. A. \& K. G. Mackenzie: Non-starchy polysaccharides of cereal grains I. Fractionation of the barley gums. J. Inst. Brew. 58, 353-362 (1952)

17. Smart, J. G.: The $\beta$-glucan content of New Zealand barley. Inst. Brew. Aust. N.Z. sec. Proc 14th Conv. 161-168 (1976)

18. Wettstein, D. von: The phytotron in Stockholm. Studia Forestalia Suecica. Number 44 (1967) 